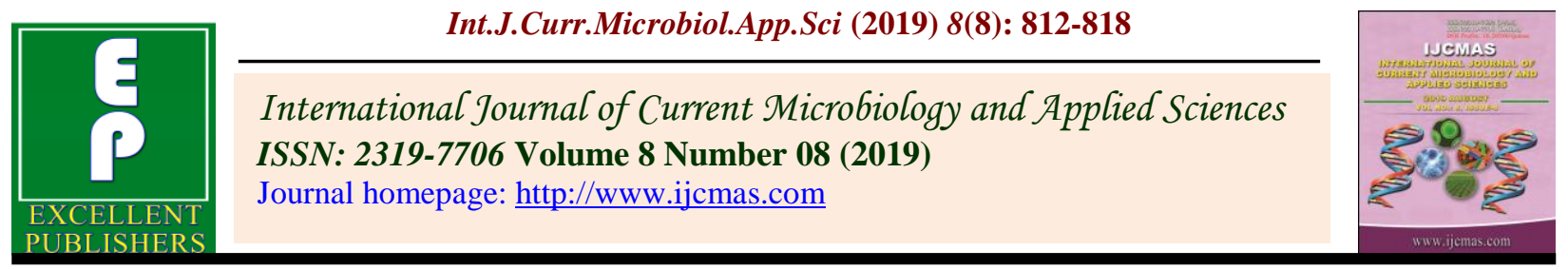

Original Research Article

https://doi.org/10.20546/ijcmas.2019.808.092

\title{
Influence of Plant Growth Substances and Bio-Fertilizers on Physiological Parameters of Vegetable Cowpea [Vigna unguiculata (L.) Walp]
}

\author{
Suresh C. Yadav ${ }^{1}$, M.R. Choudhary ${ }^{1 *}$, Pushpa Ujjainiya ${ }^{1}$ and B.L. Yadav $^{2}$ \\ ${ }^{1}$ Department of Horticulture, S. K. N. Agriculture University, Jobner, Jaipur \\ (Rajasthan) 303329, India \\ ${ }^{2}$ Soil Science, SKN Agriculture University, Jobner, India \\ *Corresponding author
}

\begin{tabular}{|l|}
\hline Ke y w o r d s \\
Relative leaf water \\
content, Transpiration \\
rate, Leaf diffusion \\
rate, Leaf osmotic \\
potential, Bio- \\
fertilizers
\end{tabular}

\section{A B S T R A C T}

This research was conducted during 2015-16 and 2016-17 kharif seasons in the Department of Horticulture, S. K. N. Agriculture University, Jobner, Jaipur (Rajasthan) to measure the influence on various physiological parameters of vegetable cowpea legume crop using growth substances and bio-fertilizers. The highest relative leaf water content $(61.90 \%)$, transpiration rate $\left(2.24 \mathrm{~m} \mathrm{~mol} \mathrm{H}_{2} \mathrm{O} / \mathrm{m}^{2} / \mathrm{s}\right)$ and leaf diffusion resistance $\left(78.03 \mathrm{~s} \mathrm{~cm}^{-2}\right)$ were obtained in Brassinoids @ 0.50 ppm whereas lowest leaf osmotic potential (1.95 -bar) was recorded under Salicylic acid @ 200 ppm with significant differences in the two seasons. Among the biofertilizers, inoculation with Rhizobium dominated over PSB and Noinoculation for maximum relative leaf water content $(60.67 \%)$, transpiration rate $\left(2.15 \mathrm{~m} \mathrm{~mol} \mathrm{H}_{2} \mathrm{O} / \mathrm{m}^{2} / \mathrm{s}\right)$ and leaf diffusion rate $\left(81.58 \mathrm{~s} \mathrm{~cm}^{-2}\right)$ and minimum leaf osmotic potential (1.95 -bar) in pooled mean of two seasons. The inoculation of PSB remained statistically at par to Rhizobium for relative leaf water content and transpiration rate.

\section{Introduction}

Vegetable cowpea [Vigna unguiculata (L.) Walp] belongs to family leguminasae, is a good source of dietary protein. It is utilized for human consumption, where the immature pods (in the case of vegetable cowpea) are eaten as vegetables (Dugje et al., 2009). It is an annual legume adapted to warm conditions and sensitive to chilling hence, is cultivated by farmers especially those with marginal, drought-prone and low rainfall areas as cowpea find very attractive to cultivate because it exhibits drought tolerance, short growing period and has multi-purpose uses (Hallensleben et al., 2009). Being a pulse crop, it also has unique ability to maintain and restore soil fertility through biological nitrogen fixation as well as addition of ample amount of residues to the soil (Aykroyd, 
1963). In present study, growth substances and bio-fertilizers were included as key factors to increase the growth, yield and quality of plants through fertilizer use efficiency as well as promote/modify the physiological responses in the plants. Brassinoids is known as a new class of plant hormone with pleiotropic effects as they influence wide array of developmental processes such as growth, seed germination, rhizogenesis flowering and maturation (Sasse, 1999). Salicylic acid (SA) is also an important substance which is classified as phenolic growth regulator, a non- enzymatic antioxidant, a signaling or messenger molecule in plants to induce responses of plants to environmental stressors (Simaei et al., 2012). Mepiquat chloride enhances reproductive organs by allowing plants to direct more energy towards reproductive structures (Wang et al., 1995). Similarly, use of bio-fertilizers can have a greater importance to increase fertilizer use efficiency and crop productivity (Vaisya et al., 1983).

Against this background, the objective of this study was to determine the influence of growth substances and bio-fertilizers on various physiological parameters of vegetable cowpea crop.

\section{Materials and Methods}

The field experiment on cowpea cv. PusaKomal was conducted during 2015-16 and 2016-17 kharif seasons at the Horticulture Research Farm, S.K.N. Agriculture University, Jobner. Geographically, Jobner is situated in Jaipur district of Rajasthan (India) at $26^{\circ} 05^{\prime}$ North latitude, $75^{\circ} 58^{\prime}$ East longitude and an altitude of 427 metres above mean sea level. This region falls under agro-climatic zone-IIIa (Semi-Arid Eastern Plains) at Horticulture farm, S.K.N. College of Agriculture, Jobner, Jaipur. The experimental soil belongs to loamy sand (soil order) with pH 8.3, ECe $1.34 \mathrm{dSm}^{-1}$, organic carbon 0.18
$\%$, Available nitrogen $131.7 \mathrm{~kg} \mathrm{ha}^{-1}$, available phosphorus $14.8 \quad \mathrm{~kg} \quad \mathrm{ha}^{-1}$ and available potassium $149 \mathrm{~kg} \mathrm{ha}^{-1}$. The experiment was laid out in randomized block design with three replications. There were total twenty treatments consisting seven levels of growth substances viz. control, mepiquat chloride 100 ppm and $200 \mathrm{ppm}$, brassinoids $0.25 \mathrm{ppm}$ and $0.50 \mathrm{ppm}$, salicylic acid $100 \mathrm{ppm}$ and 200 ppm) and three inoculation with bio-fertilizers (control, PSB and Rhizobium). The recommended dose of N P K was @ 25, 50 and $50 \mathrm{~kg} \mathrm{ha}^{-1}$, respectively as basal dose only. Mepiquat chloride, brassinoids and salicylic acid were applied as foliar spray in the plots as per treatment at 20 and 40 days after sowing.To apply biofertilizers, the liquid of Rhizobium and PSB were used @ $5 \mathrm{ml} / \mathrm{kg}$ of seed. The seeds were coated thoroughly with the solution of culture as per treatments and were allowed to air dry in shade. All the recommended package of practices was followed to raise the crop during both the years of study. Observations on per cent relative water content (RLWC) was calculated by the formula given by Slavik (1974)

$$
\text { Fresh weight - Dry weight }
$$

$$
\begin{gathered}
\text { RLWC }(\%)=\text { Turgid weight - Dry weight } \\
\text { Th }
\end{gathered}
$$

Transpiration rate $\left(\mathrm{mmol} \mathrm{H}_{2} \mathrm{O} \mathrm{m}^{-2} \mathrm{~s}^{-1}\right.$ ) and Leaf diffusion resistance $\left(\mathrm{s} \mathrm{cm}^{-2}\right)$ was measured directly with the help of Infra Red Gas Analyzer (CID INC, CI-301) and Leaf osmotic potential (-bar) was determined with the help of conductivity meter (Janardhan et al., 1975) and calculated with the help of following formula.

Fresh weight $\mathrm{x}$ Volume made

Dilution Factor $=$

Fresh weight - Dry weight

The osmotic potential of extract was calculated using following formula: 


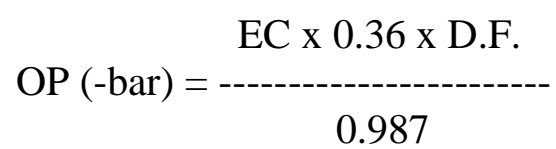

Where, $\mathrm{OP}=$ Osmotic potential, $\mathrm{EC}=$ Electrical conductivity, D.F. $=$ Dilution factor

Fresh green pod were plucked at right stage at weekly interval and weight was recorded with the help of single pan balance. The total of each plant was expressed pod yield per plant in gram. The B: $\mathrm{C}$ ratio was computed by dividing gross returns with cost of cultivation for each treatment.

\section{Results and Discussion}

\section{Physiological parameters}

Data presented in table 1 reveals that the application of growth substances significantly increased the relative leaf water content, transpiration rate and leaf diffusion resistance and decreased osmotic potential in cowpea leaves during pooled analysis of two years. The significantly higher relative water content $(61.90 \%)$, transpiration rate $\left(2.24 \mathrm{mmol} \mathrm{H}_{2} \mathrm{O}\right.$ $\left.\mathrm{m}^{-2} \mathrm{~s}^{-1}\right)$ and leaf diffusion resistance $(78.03 \mathrm{~s}$ $\mathrm{cm}^{-2}$ ) were recorded under application of brassinoids $0.50 \mathrm{ppm}$ and minimum leaf osmotic potential of 1.95 (-bar) was recorded in salicylic acid 200 ppm during pooled analysis. However, in all above physiological parameters brassinoid $0.50 \mathrm{ppm}$, salicylic acid 100 and salicylic acid 200 ppm were found statistically at par with each other. Levitt's (1972) suggested, "The capacity of a genotype to maintain relatively high water content can be considered a tolerance mechanism". In the present study leaf relative water content increased significantly under growth substances. The present investigation also indicates the significant role of brassinoids @ $0.50 \mathrm{ppm}$ in increasing the water content in cowpea. Homobrassinolide application increased leaf relative water content in wheat genotypes (Sairam, 1994). Subramanian and Maheswari (1990) reported that the intensity of water stress increased efficiency of retention of water potential by leaf tissue with per unit decrease in transpiration rate. It was reported that increase in transpiration rate on account of brassinoids @ 0.50 ppm is one of the factor imparting drought resistance (Bora and Kumar, 1990). Homobrassinolide application increased transpiration rate and recovered plant (Sairam, 1994). The highest transpiration rate was obtained with brassinoids@ 0.50 ppm and lowest with control.

The bio-fertilizers were also significantly influenced the relative leaf water content, transpiration rate, leaf diffusion resistance and leaf osmotic potential of cowpea (Table 1). The significantly higher relative water content $(60.67 \%)$, transpiration rate $\left(2.15 \mathrm{mmol} \mathrm{H}_{2} \mathrm{O}\right.$ $\left.\mathrm{m}^{-2} \mathrm{~s}^{-1}\right)$ and leaf diffusion resistance $(81.58 \mathrm{~s}$ $\mathrm{cm}^{-2}$ ) and lower leaf osmotic potential (1.95 bar) were observed in Rhizobium inoculation and it was found significantly superior over rest of the treatments. Seed inoculation with Rhizobium significantly enhanced the relative water content, transpiration rate and leaf diffusion resistance and reduced leaf osmotic potential over control. The increase in these values due to inoculation of seed with Rhizobium was probably due to more fixation of nitrogen resulting in to better utilization of nutrients by plants, Similar results have also been reported by Sajitha et al., (2007) and Nahrawy and Omara (2017).

Green pod yield per plant (g) and B: C ratio

It is evident from the data (Table 2) that application of different growth substances had significant influence on the green pod yield per plant and B: $\mathrm{C}$ ratio in pooled analysis of two years. 
Table.1 Effect of growth substances and bio-fertilizers on relative leaf water content (RLWC), transpiration rate, leaf osmotic potential and leaf diffusion resistance (Pooled mean of two years)

\begin{tabular}{|c|c|c|c|c|}
\hline Treatments & RLWC (\%) & $\begin{array}{c}\text { Transpiratio } \\
\text { n rate } \\
\left(\mathrm{m} \mathrm{mol} \mathrm{H}_{2} \mathrm{O}\right. \\
\left.\mathrm{m}^{-2} \mathrm{~s}^{-1}\right)\end{array}$ & $\begin{array}{l}\text { Leaf osmotic } \\
\text { potential (- } \\
\text { bar) }\end{array}$ & $\begin{array}{c}\text { Leaf } \\
\text { diffusion } \\
\text { resistance (s } \\
\left.\mathrm{cm}^{-2}\right)\end{array}$ \\
\hline \multicolumn{5}{|l|}{ Growth substances } \\
\hline $\mathbf{G}_{0}$ Control- (Water spray) & 46.40 & 1.69 & 2.69 & 62.08 \\
\hline $\mathrm{G}_{1}$ (Mepiquat chloride-100 ppm) & 54.28 & 1.93 & 2.43 & 71.40 \\
\hline $\mathrm{G}_{2}$ (Mepiquat chloride-200 ppm) & 55.36 & 1.98 & 2.37 & 72.21 \\
\hline $\mathrm{G}_{3}$ (Brassinoids- $\left.0.25 \mathrm{ppm}\right)$ & 56.43 & 2.11 & 2.15 & 74.27 \\
\hline $\mathrm{G}_{4}$ (Brassinoids-0.50 ppm) & 61.90 & 2.24 & 2.11 & 78.03 \\
\hline $\mathrm{G}_{5}$ (Salicylic acid - 100 ppm) & 60.77 & 2.20 & 1.97 & 77.11 \\
\hline $\mathbf{G}_{6}($ Salicylic acid - 200 ppm) & 60.46 & 2.19 & 1.95 & 76.49 \\
\hline SEm \pm & 1.27 & 0.03 & 0.03 & 1.02 \\
\hline $\mathrm{CD}(\overline{\mathrm{P}}=\mathbf{0 . 0 5})$ & 3.58 & 0.09 & 0.09 & 2.88 \\
\hline \multicolumn{5}{|l|}{ Bio-fertilizers } \\
\hline $\mathbf{B}_{0}$ (No inoculation) & 50.53 & 1.92 & 2.41 & 61.81 \\
\hline $\mathrm{B}_{1}$ (PSB inoculation) & 58.36 & 2.09 & 2.36 & 75.86 \\
\hline $\mathbf{B}_{2}$ (Rhizobium inoculation) & 60.67 & 2.15 & 1.95 & 81.58 \\
\hline SEm \pm & 0.83 & 0.02 & 0.02 & 0.67 \\
\hline $\mathrm{CD}(\mathrm{P}=0.05)$ & 2.34 & 0.06 & 0.06 & 1.88 \\
\hline
\end{tabular}

Table.2 Effect of growth substances and bio-fertilizers on Green pod yield per plant and B: C ratio (Pooled mean of two years)

\begin{tabular}{|c|c|c|}
\hline Treatments & Green pod yield per plant (g) & B:C ratio \\
\hline \multicolumn{3}{|l|}{ Growth substances } \\
\hline $\mathbf{G}_{0}$ Control- (Water spray) & 55.72 & 2.87 \\
\hline $\mathrm{G}_{1}$ (Mepiquat chloride-100 ppm) & 62.73 & 3.35 \\
\hline $\mathrm{G}_{2}$ (Mepiquat chloride-200 ppm) & 65.76 & 3.55 \\
\hline $\mathrm{G}_{3}($ Brassinoids- $-0.25 \mathrm{ppm})$ & 66.50 & 3.62 \\
\hline $\mathrm{G}_{4}($ Brassinoids-0.50 ppm $)$ & 72.75 & 4.05 \\
\hline $\mathrm{G}_{5}$ (Salicylic acid - $100 \mathrm{ppm}$ ) & 69.52 & 3.81 \\
\hline $\mathrm{G}_{6}($ Salicylic acid - $200 \mathrm{ppm})$ & 66.83 & 3.61 \\
\hline SEm \pm & 1.42 & 0.09 \\
\hline $\mathrm{CD}(\mathrm{P}=\mathbf{0 . 0 5})$ & 4.00 & 0.26 \\
\hline \multicolumn{3}{|l|}{ Bio-fertilizers } \\
\hline $\mathbf{B}_{0}$ (No inoculation) & 56.11 & 2.90 \\
\hline $\mathbf{B}_{1}(\mathrm{PSB}$ inoculation) & 66.92 & 3.63 \\
\hline $\mathbf{B}_{2}$ (Rhizobium inoculation) & 74.03 & 4.12 \\
\hline SEm \pm & 0.93 & 0.06 \\
\hline $\mathrm{CD}(\mathrm{P}=\mathbf{0 . 0 5})$ & 2.62 & 0.17 \\
\hline
\end{tabular}


Table.3 Interactive effect of growth substances and bio-fertilizers on green pod yield per plant and $\mathrm{B}$ : $\mathrm{C}$ ratio (Pooled mean of two years)

\begin{tabular}{|c|c|c|c|c|c|c|}
\hline \multirow[b]{2}{*}{ Treatments } & \multicolumn{3}{|c|}{ green pod yield per plant (g) } & \multicolumn{3}{|c|}{ B: C ratio } \\
\hline & $\begin{array}{c}\mathrm{B}_{0} \\
\text { (No } \\
\text { inoculation) }\end{array}$ & $\begin{array}{c}\mathrm{B}_{1} \\
\text { (PSB) }\end{array}$ & $\begin{array}{c}\mathrm{B}_{2} \\
\text { (Rhizobi } \\
\text { um) }\end{array}$ & $\begin{array}{c}\mathrm{B}_{0} \\
\text { (No } \\
\text { inoculation) }\end{array}$ & $\begin{array}{c}\mathrm{B}_{1} \\
(\mathrm{PSB})\end{array}$ & $\begin{array}{c}\mathrm{B}_{2} \\
\text { (Rhizobiu } \\
m \text { ) }\end{array}$ \\
\hline $\mathbf{G}_{0}$ Control- (Water spray) & 53.47 & 56.31 & 57.37 & 2.72 & 2.91 & 2.98 \\
\hline$G_{1}$ (Mepiquat chloride - 100 ppm) & 57.55 & 64.05 & 66.58 & 3.00 & 3.44 & 3.61 \\
\hline$G_{2}$ (Mepiquat chloride -200 ppm) & 59.57 & 67.16 & 70.56 & 3.13 & 3.64 & 3.87 \\
\hline $\mathrm{G}_{3}($ Brassinoids $-0.25 \mathrm{ppm})$ & 55.06 & 68.24 & 76.19 & 2.83 & 3.73 & 4.28 \\
\hline $\mathrm{G}_{4}($ Brassinoids $-0.50 \mathrm{ppm})$ & 58.83 & 72.84 & 86.60 & 3.09 & 4.05 & 5.00 \\
\hline $\mathrm{G}_{5}$ (Salicylic acid - 100 ppm) & 54.66 & 70.42 & 83.49 & 2.79 & 3.87 & 4.78 \\
\hline $\mathrm{G}_{6}($ Salicylic acid - 200 ppm) & 53.67 & 69.41 & 77.41 & 2.71 & 3.79 & 4.34 \\
\hline SEm \pm & & 2.46 & & & 0.16 & \\
\hline $\mathrm{CD}(\overline{\mathrm{P}}=\mathbf{0 . 0 5})$ & & 6.93 & & & 0.44 & \\
\hline
\end{tabular}

The maximum green pod yield per plant $(72.75 \mathrm{~g})$ and $\mathrm{B}: \mathrm{C}$ ratio (4.05) were obtained in brassinoids $0.50 \mathrm{ppm}$ while minimum (55.72 $\mathrm{g}$ and 2.87 , respectively) were noticed under control. The increase in green pod yield per plant under this treatment was registered as 30.56 per cent higher over control.

The green pod yield per plant and B: C ratio were also significantly influenced with the inoculation of bio-fertilizers in pooled analysis.

The maximum pod yield per plant (74.03 g) and B: C ratio (4.12) were recorded under Rhizobium inoculation, while found minimum (56.11 g and 2.90, respectively) under control. The increase in green pod yield per plant was noted 31.94 per cent higher over control.

The interactive effect of growth substances and bio-fertilizers was significantly influenced the green pod yield and B: C ratio.

The data (Table 3 ) revealed that the maximum pod yield per plant $(86.60 \mathrm{~g})$ and $\mathrm{B}$ : $\mathrm{C}$ ratio (5.00) was recorded under treatment combination of brassinoids $0.50 \mathrm{ppm}$ along with Rhizobium inoculation.
The increase in yield and yield attributes under foliar spray of brassinoid was also observed by Takemastsy et al., (1983). GograjJat et al., (2012) and Choudhary (2017) also reported that brassinoids and salicylic acid were found to be most effective. Brassinoids seems to be superior than salicylic acid to influence physiological parameters of plant and directly and indirectly yield (Maity and Bera, 2009).

The beneficial effects of Rhizobium inoculation might have increased the availability of nitrogen and phosphorus along with other nutrients which in term resulted into higher production of assimilates and their partitioning to different reproductive structures such as yield attributes and ultimately, green pod yield. Co-inoculation of legumes with Rhizobium and PSB strains, were able to alleviate salt stress of plants, grown on salt affected soils and ultimately increase the plant growth, yield and control the plant diseases of leguminous plants (Egamberdieva and Jabborova, 2013).

The study showed that the application of brassinoids $0.50 \mathrm{ppm}$ and seed inoculation with Rhizobium bio-fertilizer significantly 
influenced physiological characters which are directly or indirectly related with yield and economic returns of cowpea plants. Thus, applications of brassinoids @ 0.50 ppm and seed inoculation with Rhizobium bio-fertilizer is hereby recommended for cowpea growers of semi-arid region under sandy loam soils.

\section{References}

Aykroyd, W.R. 1963. ICMR Special Report, Series, No. 42.

Bora, K.K. and Kumar, A. 1990.Physiology of drought tolerance in pearlmillet. Acta Ecol., 12: 1-5.

Choudhary, K.K. 2017. Effect of brassinolide on physiological aspects, growth and yield of wheat (Triticum aestivum L.) under salt stress. M.Sc. (Ag.) thesis, submitted to $\mathrm{S}$. K. N. Agriculture University, Jobner, Jaipur.

Dugje, I. Y., Omoigui, L.O, Ekeleme, F., Kamara, A.Y. and Ajeigbe, H. 2009. Farmers' guide to cowpea production in West Africa. International Institute of Tropical Agriculture, Ibadan, Nigeria.24 pp.

Egamberdieva, D. and Jabborova, D. 2013. Alleviation of salt stress in legumes by co- inoculation with Pseudomonas and Rhizobium plant microbe symbiosis. Fundamentals and Advances, 4 (11): 978-81.

GograjJat, Bagdi, D.L., Kakralya, B.L., Jat, M.L. and Shekhawat, P.S. 2012. Mitigation of salinity induced effects using brassinolide in clusterbean (Cyamopsis tetragonoloba L.). Crop Research (Hisar), 44 (1/2): 45-50.

Hallensleben, M., Polreich, S., Heller, J. and Maass, B.L. 2009. Assessment of the importance and utilization of cowpea (Vigna unguiculata L. Walp.) as leafy vegetable in small-scale farm households in Tanzania - East Africa. Conference of International Research on Food Security, Natural Resource Management and Rural Development, 2009, University of Hamburg, Tropentag, October 6-8, 2009.

Janardhan, K.V., Murthy, A.S.P., Giriraj, K. and Panchaksharaiah, S. 1975. A rapid method for determination of osmotic potential of plant cell sap. Current Sci., 44: 390.

Levitt, J. 1972. Responses of plants to environmental stress.Vol.2. Academic Press, New York, USA.

Maity, U. and Bera, A.K. 2009. Effect of exogenous application of brassinolide and salicylic acid on certain physiological and biochemical aspects of green gram (Vigna radiate L. Wilczek). Indian J. Agric. Res., 43 (3): 194-199.

Nahrawy, S.E. and Omara, A.E.D. 2017. Effectiveness of co-inoculation with Pseudomonas koreensis and Rhizobiam on growth, nodulation and yield of common bean (Phaseolus vulgaris L.). Microbiology Research Journal International, 21 (6): 1-15.

Sairam, R.K. 1994. Effect of moisture stress on physiological activities of two contrasting wheat genotypes. Indian Journal of Expt. Biology, 32: 594-597.

Sajitha, J.P., Haripriya, K., Maheswari, T.U. and Stella, D. 2007. Impact of organic nutrients on yield and quality of garden bean. Acta Horticulture, 752: 485-487.

Sasse, J.M. 1999. Physiological actions of brassinostroids in: A Sakurai, T. Yokota and S.D. Clouse (eds.) brassinostroids. Steroidal Plant Hormones, 137-161.

Simaei, M., Khavari-Nejad, R.A. and Bernard, F. 2012. Exogenous application of salicylic acid and nitric oxide on the ionic contents and enzymatic activities in $\mathrm{NaCl}$-stressed soybean plants. American Journal of Plant Sciences, 3: 1495-1503. 
Slavik, B. 1974. Methods of studying plant water relations. Springer Verlag. New York.

Subramanian, V.B. and Maheswari, B. 1990. Physiological responses of groundnut to water stress. Indian Journal of Plant Physiology, 33: 130-135.

Takemastsy, T.Y., Takenchi, and Koguchi, M. 1983. New plant growth regulators. Brassinolide analogues their biological effects and application to agriculture and biomass production. Chemical Regulators Plant, 18: 2-15.
Vaisya, V.K., Gayendregdkar, G.R. and Penday, R.L. 1983. Effect of Rhizobium inoculation on nodulation and grain yield of mungbean. Indian Journal of Microbiology, 23 (4): 228-230.

Wang, Z., Y. Yanping, and S. Xuezhen. 1995. The effect of DPC (N,N-dimethyl piperidinium chloride) on the $14 \mathrm{CO}_{2^{-}}$ assimilation and partitioning of $14 \mathrm{C}$ assimilates within the cotton plants interplanted in a wheat stand. Photosynthetica, 31: 197-202.

\section{How to cite this article:}

Suresh C. Yadav, M.R. Choudhary, Pushpa Ujjainiya and Yadav, B.L. 2019. Influence of Plant Growth Substances and Bio-Fertilizers on Physiological Parameters of Vegetable Cowpea [Vigna unguiculata (L.) Walp]. Int.J.Curr.Microbiol.App.Sci. 8(08): 812-818. doi: https://doi.org/10.20546/ijcmas.2019.808.092 